\title{
Does adding extracorporeal shock wave therapy to postural correction exercises improve pain and functional disability in postpartum sacroiliac joint pain? A randomized controlled trial
}

\section{¿La adición de la terapia de ondas de choque extracorpóreas a los ejercicios de corrección postural mejora el dolor y la diversidad funcional en el dolor de la articulación sacroilíaca posparto? Un ensayo controlado aleatorizado}

\author{
Eman Abdelfatah Mohamed Elhosary ${ }^{1}$, Hamada Ahmed Hamada ${ }^{2 *}$, Mahmoud Ewidea ${ }^{3}$, \\ Abdullah M. Al-Shenqiti ${ }^{4}$, Yassmin Essam Mohamed ${ }^{2}$ \\ ${ }^{1}$ Department of Physical Therapy for Women's Health, Faculty of Physical Therapy, Kafrelsheikh \\ University, Egypt. \\ ${ }^{2}$ Department of Biomechanics, Faculty of Physical Therapy, Cairo University, Egypt. \\ ${ }^{3}$ Department of Basic Science, Faculty of Physical Therapy, Kafrelshiekh University, Kafrelshiekh, \\ Egypt. \\ ${ }^{4}$ Faculty of Medical Rehabilitation Sciences, Taibah University, KSA. \\ * Correspondence: Hamada Ahmed Hamada; hamada.ahmed@pt.cu.edu.eg
}

\begin{abstract}
Examining the outcome of the extracorporeal shock wave therapy (ESWT) on females with postpartum sacroiliac joint pain was the aim of this study. Forty primigravida (six weeks postpartum) females with sacroiliac pain was the sample in this study. The subjects equally randomly allocated in group A and B. Group A was treated by ESWT in addition to postural correction and posterior pelvic tilting exercises. Group B was treated by the same exercise program only. Two sessions every week for four weeks were received by both groups. The measurement variables were sacroiliac pain and function level that were measured by visual analogue scale (VAS) and the back pain functional scale (BPFS), respectively. All measurements were evaluated pre and post four weeks of intervention. The within groups analysis showed a significant improvement in VAS and a significant increase in BPFS in both groups after treatment compared with baseline. Regarding between groups analyses there was a significant improvement in VAS and a significant increase in BPFS in group A compared with group B. In conclusion, both ESWT and exercise program are effective in decreasing the pain and improving the function in females with postpartum sacroiliac pain. However, by adding ESWT to exercises in the
\end{abstract}


Mohamed Elhosary et al.

treatment program the results are better, so this combination is recommended in treatment of females with postpartum sacroiliac pain.

\section{KEYWORDS}

Postpartum sacroiliac pain; Shockwave therapy; Posture correction; BPFS.

\section{RESUMEN}

El objetivo de este estudio fue examinar el resultado de la terapia de ondas de choque extracorpóreas (TOCH) en mujeres con dolor en la articulación sacroilíaca posparto. Cuarenta mujeres primigrávidas (seis semanas después del parto) con dolor sacroilíaco participaron en este estudio. Fueron asignadas al azar a los grupos A y B. El grupo A fue tratado mediante TOCH, además de ejercicios de corrección postural y ejercicios de inclinación pélvica posterior. El grupo B fue tratado únicamente con el mismo programa de ejercicios. Ambos grupos recibieron dos sesiones por semana durante cuatro semanas. Las variables estudiadas fueron el dolor sacroilíaco y el nivel de función, las cuales se midieron mediante la escala visual analógica (EVA) y la escala funcional de dolor de espalda (EFDE), respectivamente. Todas las mediciones se evaluaron antes y después de las cuatro semanas de intervención. El análisis dentro de los grupos mostró una mejora significativa en la EVA y un aumento significativo en la EFDE en ambos grupos después del tratamiento en comparación con el valor inicial. Con respecto a los análisis entre grupos, hubo una mejora significativa en la EVA y un aumento significativo en la EFDE en el grupo A en comparación al grupo B. En conclusión, tanto la TOCH como el programa de ejercicios son efectivos para disminuir el dolor y mejorar la función en mujeres con dolor sacroilíaco posparto. Sin embargo, al agregar TOCH a los ejercicios en el programa de tratamiento, los resultados son mejores, por lo que esta combinación se recomienda en el tratamiento de mujeres con dolor sacroilíaco posparto

\section{PALABRAS CLAVE}

Dolor sacroilíaco posparto; Terapia de ondas de choque; Corrección de postura; BPFS.

\section{INTRODUCTION}

Postpartum is a time that starts from the birth of a child and continue about 6 weeks. During pregnancy and postpartum there are many changes in the bone alignment, especially around the pelvis (Pennick \& Liddle, 2015; Sipko, Grygier, Barczyk \& Eliasz, 2010). Increased pelvic asymmetry is an example of pelvic alignment changes that is considered a risk factor for sacroiliac joint pain (Morino et al., 2018). The biomechanical stresses during this period may lead to micro trauma that activates the 
stress genes and increases the response of adhesion molecules (Mc Gonagle, Stockwin, Isaacs \& Emery, 2001). In $63.3 \%$ of early postpartum women the bone marrow edema at the sacroiliac joints was due to these prolonged mechanical stresses (Agten et al., 2018). Additionally, pregnancy-related hormones lead to increase joints elasticity, such as the sacroiliac joint that may direct to misalignments in the body (Schauberger et al., 1996). About 26\% of postpartum women suffered from sacroiliac joint dysfunction (Ghodke, Shete, \& Anap, 2017).

Normally at the period from 6 weeks to 6 months postpartum, the tone of muscles and soft tissue regain to their normal state (Romano, Cacciatore, Giordano, \& La Rosa, 2010). However, in some cases, these changes don't resolve and become a chronic character. There are many explanations as the ligaments that stabilize the joint remain loose, which causes joint pain due to the effect of repetitive new movement at joint. Moreover, joint locking may occur due to this new movement that may hinder normal joint movement (Magee, 2013).

Different interventions have been used to control the pelvic pain, including drugs, exercise and manual therapy, hydrotherapy, electrotherapy as laser, ultrasound and short wave, acupuncture, and belt (Perry, 2013). A systematic review of treatment methods to reduce pelvic or back pain in pregnancy suggested that the evening pelvic pain was reduced more effectively by exercise therapy than usual care alone (Pennick \& Liddle, 2013). Moreover, posture correction exercises have an important role in maintaining muscles and skeleton balance through minimizing the strain on the human body (Chen et al., 2008). Posture correction exercises are an effective treatment for relieving pelvic pain in postpartum females (Kim, Cho, Park, \& Yang, 2015).

Recently, to reduce the lumbo-pelvic pain and improve its function, the extracorporeal shock wave therapy (ESWT) has been used as a good method of treatment (Lee, Lee, \& Park, 2014; Lin et al., 2004; Han, Lee, Lee, Jeon \& Kim, 2015; Tomska et al., 2018). This method of treatment seems to be more effective than conventional motor improvement programs (Walewicz et al., 2019). Now, ECSWT is used to decrease inflammation and enhance new tissue formation in many disorders (Romeo, Lavanga, Pagani, \& Sansone, 2014). Thus, the purpose of this study was to examine the effect of the ESWT on pain and function in females with postpartum sacroiliac joint pain.

\section{METHODS}

\subsection{Study Design}

This study was designed as randomized, single-blind, pre-test and post-test, and controlled trial. Ethical approval was obtained from the ethical committee of the Faculty of Physical Therapy of Cairo 
University before the study (number P. T.REC/012/002927). The study began in April 2019 and was completed in March 2020. The objectives and the procedures of the study were explained to all participants and their voluntary agreement to participate was obtained with informed consent. Also, all participants had the right to withdraw at any time from the study. Additionally, the participants were sure about the confidentiality of any obtained information.

\subsection{Participants}

Forty primigravida, six weeks postpartum females with sacroiliac joint pain participated in this study. The patients attended the Outpatient Clinic in the Faculty of Physical Therapy and the Women Health Unit of Kafr Elsheikh University (Egypt). All patients were evaluated for their suitability to participate in the study, with the following inclusion criteria: to have unilateral or bilateral pain in back or sacral area (positive posterior pain provocation test for sacroiliac joint dysfunction), to be 20-35 years old and to have a BMI that did not exceed $32 \mathrm{~kg} / \mathrm{m}^{2}$. Patients were excluded if they had had any surgery, infection, deformity, tumor and/or fracture in the lumbar vertebrae region or if they had any heart disease.

A blinded independent research assistant randomly assigned all participants into two groups (group A and group B). The randomization was carried out by opening closed covers with a computer generated randomization card. After randomization no subjects withdraw from the study. Group A was composed of 20 females who received ESWT with an experienced physical therapist in the women health unit, 2 times weekly for 4 weeks, furthermore to exercise for postural correction and posterior pelvic tilting exercises. Group B was composed of 20 females who followed the same postural correction and posterior pelvic tilting exercises, two sessions per week for 4 weeks.

\subsection{Procedure}

Patient in group A received ESWT by using the shock master 500 German with $8 \mathrm{~Hz}$ frequency, 2400 pulses, and pressure was set at 4 bars that correspond to an energy flux density of $0.11 \mathrm{~mJ} / \mathrm{mm} 2$. Patients were asked to assume a prone lying position. The application was conducted by a direct contact method applied at the sacroiliac joint and the quadratus lumborum muscle (the site of pain) (Figure 1). To reduce the tissue resistance and improve the energy propagation, a lubricant was used. All patients in this group received 2 sessions every week for 4 weeks. 


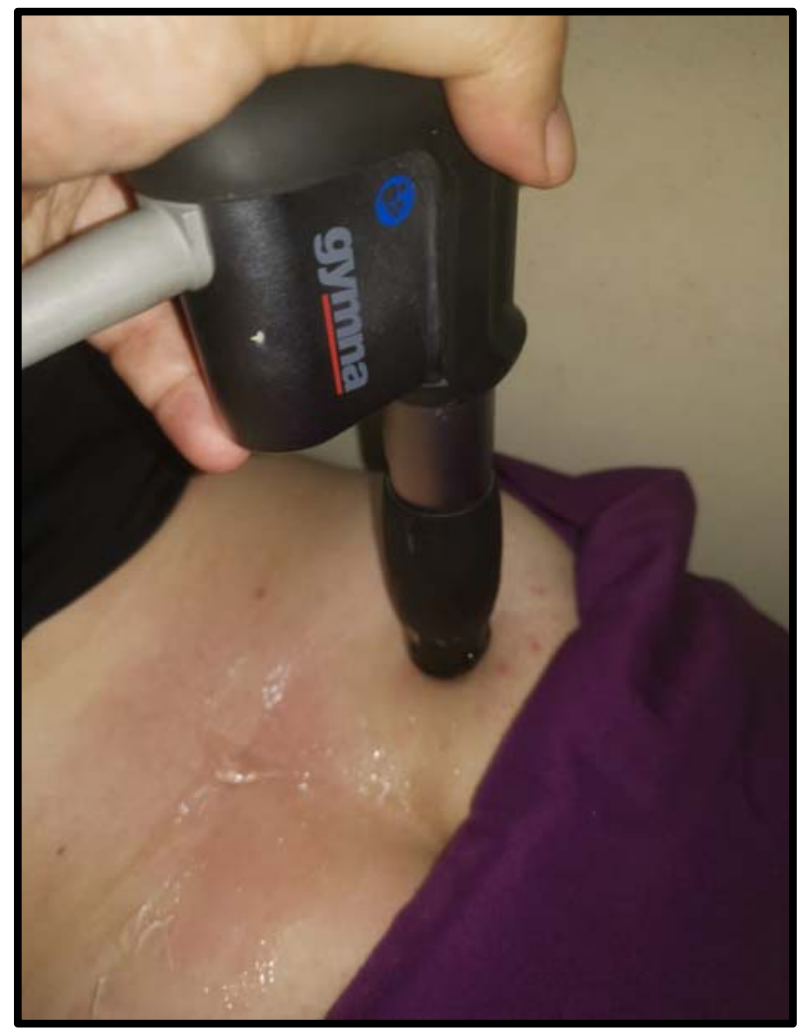

Figure 1. Application of shock wave on sacroiliac pain

Patients in group A and B were instructed to perform postural correction exercise (by dorsiflexion of both ankles, press knee down, contract glutei, press lumber against the plinth, contract abdominal muscles, perform costal breathing, and chin in) and then hold for 3 seconds and relax for 6 seconds. The patients were asked to perform the posture correction exercises from supine lying position, then from sitting position and then standing. This exercise was performed by all patients in both groups by asking them to assume crock lying position, contract their abdominal muscles, press the lumbar region down for 3 seconds and then relax 6 seconds. In each session this exercise was repeated 10 times.

\subsection{Outcome Measures}

Before treatment and after 4 weeks all participants were assessed. The measurement variables were sacroiliac pain via using Visual Analogue Scale (VAS) and patients function level by using Back Pain Function Scale (BPFS). The VAS is a graphic rating scale which is valid for pain intensity measurement. The length of line is $10 \mathrm{~cm}$, it begins with one end indicating no pain (zero), and the other end of the line indicates the worst pain (ten). Each participant was instructed to grade their level of pain by scoring on the line at the point that denoting her pain sensation (Bijur, Silver, \& Gallagher, 2001). BPFS consists of 12 objects of daily activities with 5 different answers. Patient's response to 
each item was reported by each participant conferring to her capability to apply this activity. Inability to perform any activity referred to zero score, while no difficulty in any activity referred to the maximum score (60). So the higher the score obtained, the better the patient's efficient ability (Stratford, Binkley \& Riddle, 2000).

\subsection{Statistical analysis}

The trial size estimation was done prior to the survey to determine the sample size by using the statistical programming G*POWER (version 3.1.9.2; Franz Faul, Universitat Kiel, Germany). The size of the effect was measured for the pilot study with 10 participants ( 5 per group). The statistical analysis was performed using Windows SPSS version 23 (SPSS, Inc., Chicago, IL). 2x2 mixed design MANOVA was used to compare the measured variables in both groups. The normality hypothesis, homogeneity of variance and the presence of extreme scores of data were examined. This scan was performed as a preliminary condition for the parameter calculations of the difference analyses. The p-value was adjusted to $<0.05$.

\section{RESULTS}

Table 1 presents the overall characteristics of both groups (A and B) at the start of the study. The inferential statistics did not show any significant difference in the average comparison for all measured parameters and for both groups (Table 1).

Table 1. General characteristics of all participants.

\begin{tabular}{lcccc}
\hline Variables & Group A $(\mathrm{n}=20)$ & Group B $(\mathrm{n}=20)$ & t-value & $\mathrm{p}$-value \\
\hline Age (years) & $25.55 \pm 3.06$ & $24.15 \pm 2.66$ & 1.541 & 0.132 \\
BMI $\left(\mathrm{Kg} / \mathrm{m}^{2}\right)$ & $28.65 \pm 1.98$ & $28.05 \pm 1.5$ & 1.079 & 0.287 \\
\hline \multicolumn{5}{c}{ Significance considered at $p<0.05}$.
\end{tabular}

Within and between groups descriptive statistics were represented in tables 2 and 3, with 95\% CI differences in the effects of the interventions. The multiple pairwise comparison tests regarding within subject effect revealed that there was a significant decrease $(p<0.05)$ in VAS score and a significant improvement in BPFS at both groups after treatment compared with before treatment. Regarding between subject effects, multiple pairwise comparisons exposed that there was a significant difference in VAS and BPFS between both groups $(\mathrm{p}<0.05)$ and this significant improvement was in favour of group A. 
Table 2. Descriptive statistics for VAS and BPFS in both groups at different training periods.

\begin{tabular}{ccccc}
\hline & \multicolumn{2}{c}{ Group (A) } & \multicolumn{2}{c}{ Group (B) } \\
\hline Variables & Pre & Post & Pre & Post \\
\hline BPFS & $20.45 \pm 5.08$ & $50.25 \pm 4.26$ & $19.7 \pm 3.62$ & $3.2 \pm 3.1$ \\
VAS & $6.95 \pm 1.23$ & $2.15 \pm 1.03$ & $7.65 \pm 1.08$ & $6.35 \pm 0.98$ \\
\hline
\end{tabular}

Values of all dependent variables are expressed as mean $\pm S D$.

Table 3. Within and between groups differences at $95 \%$ CI for the effects of interventions. Within groups Between groups Group (A) Group (B) Mean difference $\quad$ Mean difference Mean difference Variables

\begin{tabular}{|c|c|c|c|c|}
\hline Variables & (050/ & $(050$ & $(95 \% \mathrm{CI})$ & \\
\hline & $29.8(27.97 \text { to } 31.62)^{*}$ & $3.5(1.67 \text { to } 5.32)^{*}$ & $26.3(25.06 \text { to } 27.54)^{*}$ & 0.8 \\
\hline VAS & $-4.8(-5.37 \text { to }-4.22)^{*}$ & $-1.3(-1.87$ to -0.725$) *$ & $-3.5(-3.83 \text { to }-3.17)^{*}$ & 0.216 \\
\hline
\end{tabular}

CI: Confidence Interval, MCID: Minimal Clinically Important Difference, * the mean difference is significant at the 0.05 level.

\section{DISCUSSION}

Exercise is a precious modality for helping females to pass the postpartum stresses (Esparza Montero, 2021; Gimunová, Zvonař, Švancara, \& Kukla, 2018; Gimunová, Zvonař, Šagat, \& Duvač, 2018; Kendall-Tackett, 2007; Yadolahzadeh, 2020). It is considered the traditional modality for minimizing the strain on the human body and relieving pelvic pain in postpartum females (Chen et al., 2008; Kim, Cho, Park \& Yang, 2015; Pérez et al., 2021; Sánchez, López, \& Zauder, 2018). However, the systematic review conducted by Gutke, Betten, Degerskar, Pousette, \& Olsen, (2015) concluded that the levels of evidence for an effect of specific exercises in controlling the lumbo pelvic pain were weak. Therefore, searching about new effective treatment for postpartum pelvic pain is an essential target. The purpose of this study was to examine the effect of ESWT on pain and function of females with postpartum pelvic pain.

The results of the study revealed that, regarding the within groups analysis, there was a significant reduction in VAS and a significant increase in BPFS in both groups after treatment compared with baseline. These results showed that both ESWT and postural correction exercises were effective in decreasing the pain and improving the function of postpartum females with sacroiliac pain. 
The results of ESWT are consistent with the majority of previous researches. Lee, Lee, \& Park (2014) stated that when ESWT and exercise program were used together in the treatment of chronic backache, they relieved pain sensation and increase dynamic balance more than an exercise program with conventional physical therapy modalities (hot packs, ultrasound and TENS). However, this study had an error in its design because both groups received exercises program in addition to another intervention and there was no control group. Additionally, it was limited by a small sample size (28 patients divided into two groups).

Moreover, ESWT was suggested as a respectable method of treatment for patients with coccydynia (Lin et al., 2015). The sample of this study was separated into 2 groups. The patients in the first group received combined therapy of shortwave diathermy and interferential current, while the second group received ESWT. The results of this study showed that the VAS score was significantly improved after treatment in the two groups, but the decrease was significantly greater in the ESWT group (Lin et al., 2015). Also Haghighat \& Mashayekhi (2016) studied the effect of ESWT on patients with chronic coccydynia. The VAS significantly decreased after two months and four weeks of treatment when compared to baseline. But it did not decrease significantly seven months after therapy. This study was limited by male sample size (ten patients in one group only).

However, the results of Walewicz et al. (2019) disagreed with the current study regarding the effect of ESWT on pain. A total of 40 patients were equally randomized into two groups. Group A was treated with ESWT and stabilization training and group B was treated with sham ESWT and stabilization training. VAS and Laitinen Pain Scale were used to assess pain and Oswestry Disability Index was used to determine functional efficiency. The control group had a statistically significant gain in pain improvement over the ESWT group when was measured after five weeks of treatment. The functional state was better in ESWT group than in the sham ESWT group. However, ESWT group had a significantly higher long-term decrease of pain sensation than sham ESWT group when it was measured after one and three months of follow up.

Regarding between groups analyses there were a significant improvement in VAS and a significant improvement in BPFS in group A in comparison with group B. In group A the aims of the interventions were directed towards two lines. First line was to correct the mechanical changes that occurred due to pregnancy and delivery (Pennick, \& Liddle, 2015; Sipko, Grygier, Barczyk, \& Eliasz, 2010; Morino et al., 2018). The second line was to try to control the joint inflammatory changes and pain (Mc Gonagle, Stockwin, Isaacs, \& Emery, 2001; Agten et al., 2018). So using ESWT in addition to posture correction exercises can be considered an effective combination to decrease postpartum 
sacroiliac pain and improve the function, which may be due to controlling both the mechanical and inflammatory changes.

The ESWT effect on pain reduction may be due to its regular effect on the inflammation (Haghighat, \& Mashayekhi, 2016).This anti-inflammatory effect may be due to interstitial and extracellular responses that lead to tissue regeneration (Wang, 2012). Moreover, ESWT decreases pain by improving tissue blood supply due to formation of neovascularization and by tissue regeneration effect. Increasing tissue blood supply leads to decrease the muscle tension and tissue adhesion (Wang et al., 2003). Additionally, ESWT decreases the inflammatory mediators like matrix metalloproteinases and interleukins (Notarnicola, \& Moretti, 2012).

There are other mechanisms which might explain the ESWT effect on pain reduction and function improvement. ESWT decreases pain by suppressive effects on nociceptors directly and hyper stimulation, which affects the gate-control system by blocking it. Its neovascularisation effect on the site of treatment was associated with the stimulated nerve fibers surrounding it (Santamato et al., 2019). Malay et al. (2006) stated that ESWT induced physical alteration of small axons, so it stopped pain impulse conduction chemical changes of pain receptor neurotransmitters and reduced pain perception.

\section{CONCLUSIONS}

The ESWT is an effective therapeutic modality to reduce pain and improve function in postpartum females with sacroiliac joint pain. Additionally, adding ESWT to traditional postural correction exercises is recommended for pain reduction and functional improvement of such cases.

\section{REFERENCES}

1. Agten, C. A., Zubler, V., Zanetti, M., Binkert, C. A., Kolokythas, O., Prentl, E., ... \& Pfirrmann, C. W. (2018). Postpartum bone marrow edema at the sacroiliac joints may mimic sacroiliitis of axial spondyloarthritis on MRI. American Journal of Roentgenology, 211(6), 1306-1312.

2. Bijur, P. E., Silver, W., \& Gallagher, E. J. (2001). Reliability of the visual analog scale for measurement of acute pain. Academic emergency medicine, 8(12), 1153-1157.

3. Chen, K. M., Chen, M. H., Hong, S. M., Chao, H. C., Lin, H. S., \& Li, C. H. (2008). Physical fitness of older adults in senior activity centres after 24-week silver yoga exercises. Journal of clinical nursing, 17(19), 2634-2646.

4. Esparza Montero, M. A. (2021). Influence of the strength of the ankle plantar flexors on dynamic balance in 55-65-year-old women. Atena Journal of Public Health, 3, 3.

5. Ghodke, P. S., Shete, D., \& Anap, D. (2017). Prevalence of Sacroiliac Joint Dysfunction in Postpartum Women-A Cross Sectional Study. Journal of Physiotherapy and Rehabilitation, 2(3), 149.

6. Gimunová, M., Zvonař, M., Šagat, P., \& Duvač, I. (2018). Cambios en la alineación de las extremidades inferiores durante la marcha en fases avanzadas del embarazo y el efecto de calzado especial. SPORT TK-Revista EuroAmericana de Ciencias del Deporte, 7(1), 111-116. 
7. Gimunová, M., Zvonař, M., Švancara, J., \& Kukla, L. (2018). El impacto de la actividad física durante el embarazo en el aumento de peso y los resultados del parto. SPORT TK-Revista EuroAmericana de Ciencias del Deporte, 7(2), 45-52.

8. Gutke, A., Betten, C., Degerskar, K., Pousette, S. \& Olsen, M. F. (2015). Treatments for pregnancy-related lumbopelvic pain: a systematic review of physiotherapy modalities. Acta Obstetricia et Gynecologica Scandinavica, 94, 1156-1167.

9. Haghighat, S., \& Mashayekhi, M. (2016). Effects of Extracorporeal Shock Wave Therapy on Pain in Patients with Chronic Refractory Coccydynia: A Quasi-Experimental Study. Anesthesia and Pain Medicine, 6(4), e37428.

10. Han, H., Lee, D., Lee, S., Jeon, C. \& Kim, T. (2015). The effects of extracorporeal shock wave therapy on pain, disability, and depression of chronic low back pain patients. The Journal of Physical Therapy Science, 27(2), 397-399.

11. Kendall-Tackett, K. (2007). A new paradigm for depression in new mothers: The central role of inflammation and how breastfeeding and anti-inflammatory treatments protect maternal mental health. International Breastfeeding Journal, 2, 6.

12. Kim, D. J., Cho, M. L., Park, Y. H., \& Yang, Y. A. (2015). Effect of an exercise program for posture correction on musculoskeletal pain. The Journal of Physical Therapy Science, 27, 17911794.

13. Lee, S., Lee, D., \& Park, J. (2014). Effects of extracorporeal shockwave therapy on patients with chronic low back pain and their dynamic balance ability. The Journal of Physical Therapy Science, 26(1), 7-10.

14. Lin, S-F., Chen, Y-J., Tu, H-P., Lee, C-L., Hsieh, C-L, Wu, W-L., \& Chen, C-H. (2015). The effects of extracorporeal shock wave therapy in patients with coccydynia: A randomized controlled trial. PLoS One, 10(11), e0142475.

15. Magee, D. J. (2013). Orthopedic physical assessment. (6th ed.). Saunders Elservier, USA. 664672 .

16. Malay, D.S., Pressman, M.M., Assili, A., Kline, J. T., York, S., Buren, B., ... \& Lemay, C. (2006). Extracorporeal Shockwave Therapy Versus Placebo for the Treatment of Chronic Proximal Plantar Fasciitis: Results of a Blinded, Multicenter Intervention Trial. The journal of foot and ankle surgery, 45(4), 196-210.

17. McGonagle, D., Stockwin, L., Isaacs, J. \& Emery, P. (2001). An enthesitis based model for the pathogenesis of spondyloarthropathy. Additive effects of microbial adjuvant and biomechanical factors at disease sites. The Journal of Rheumatology, 28(10), 2155-2159.

18. Morino, S., Ishihara, M., Umezaki, F., Hatanaka, H., Yamashita, M., Aoyama, T. \& Takahashi, M. (2018). Pelvic alignment risk factors associated with sacroiliac joint pain during pregnancy. Clinical and Experimental Obstetrics \& Gynecology, 45, 850-854.

19. Notarnicola, A., \& Moretti, B. (2012). The biological effects of extracorporeal shock wave therapy (ESWT) on tendon tissue. Muscle, Ligaments and Tendons Journal, 2(1), 33-37.

20. Liddle, S. D., \& Pennick, V. (2015). Interventions for preventing and treating low-back and pelvic pain during pregnancy. Cochrane Database of Systematic Reviews, 8(8), 1-9.

21. Pérez Muñoz, S., Morilla de la Riva, D., Alonso García, G., Sánchez Muñoz, A., Albert García, F., \& Rodríguez Cayetano, A. (2021). Efecto del entrenamiento de fuerza en deportistas femeninas de deportes colectivos mediante tecnología isoinercial. SPORT TK-Revista EuroAmericana de Ciencias del Deporte, 10(1), 79-86.

22. Perry, M. (2013). Low back pain: tackling a common problem. Practice Nursing, 24, 356-358.

23. Romano, M., Cacciatore, A., Giordano, R., \& La Rosa, B. (2010). Postpartum period: three distinct but continuous phases. Journal of prenatal medicine, 4(2), 22-25.

24. Romeo, P., Lavanga, V., Pagani, D., \& Sansone, V. (2014). Extracorporeal shock wave therapy in musculoskeletal disorders: a review. Medical Principles and Practice, 23(1), 7-13. 
25. Sánchez-Mompeán, S., López-Sánchez, G. F., \& Zauder, R. (2018). Traducción y adaptación transcultural al castellano del Pregnancy Physical Activity Questionnaire (PPAQ). Education, Sport, Health and Physical Activity (ESHPA), 2(2), 124-144.

26. Santamato, A., Beatrice, R., Micello, M.F., Fortunato, F., Panza, F., Bristogiannis, C., ... \& Ranieri, M. (2019). Power doppler ultrasound findings before and after focused extracorporeal shock wave therapy for achilles tendinopathy: a pilot study on pain reduction and neovascularization effect. Ultrasound in Medicine and Biology, 45(5), 1316-1323.

27. Schauberger, C. W., Rooney, B. L., Goldsmith, L., Shenton, D., Silva, P. D. \& Schaper, A. (1996). Peripheral joint laxity increases in pregnancy but does not correlate with serum relaxin levels. American Journal of Obstetrics and Gynecology, 174, 667-671.

28. Sipko, T., Grygier, D., Barczyk, K., \& Eliasz, G. (2010). The occurrence of strain symptoms in the lumbosacral region and pelvis during pregnancy and after childbirth. Journal of Manipulative and Physiological Therapeutics, 33, 370-377.

29. Stratford, P. W., Binkley, J. M., \& Riddle, D. (2000). Development and initial validation of the Back Pain Functional Scale. Spine, 25, 2095-2102.

30. Tomska, N., Turoń-Skrzypińska, A., Szylińska, A., Rył, A., Lubińska-Gruszka, A., Mosiejczuk, H. \& Rotter, I. (2018). Deep electromagnetic stimulation and radial shock wave therapy in back pain. Ortopedia Traumatologia Rehabilitacja, 20(3), 189-195.

31. Walewicz, K., Taradaj, J., Rajfur, K., Ptaszkowski, K., Kuszewski, M.T., Sopel, M., \& Dymarek, R (2019). The Effectiveness of Radial Extracorporeal Shock Wave Therapy in Patients with Chronic Low Back Pain: A Prospective, Randomized, Single-Blinded Pilot Study. Clinical Interventions in Aging, 14, 1859-1869.

32. Wang, C. J. (2012). Extracorporeal shockwave therapy in musculoskeletal disorders. Journal of Orthopaedic Surgery and Research, 7, 11.

33. Wang, C. J., Wang, F. S., Yang, K. D., Weng, L. H., Hsu, C. C., Huang, C. S., \& Yang, L. C. (2003). Shock wave therapy induces neovascularization at the tendon-bone junction. A study in rabbits. Journal of Orthopaedic Research, 21(6), 984-989.

34. Yadolahzadeh, A. (2020). The role of mental imagery and stress management training in the performance of female swimmers. Atena Journal of Sports Sciences, 3(1), 1.

\section{AUTHOR CONTRIBUTIONS}

All authors listed have made a substantial, direct and intellectual contribution to the work, and approved it for publication.

\section{CONFLICTS OF INTEREST}

The authors declare no conflict of interest.

\section{FUNDING}

This research received no external funding.

\section{COPYRIGHT}

(C) Copyright 2021: Publication Service of the University of Murcia, Murcia, Spain. 